\title{
The American Civil Rights Tradition: Anticlassification or
}

\section{Antisubordination?}

\author{
Jack M. Balkin* \\ Reva B. Siegel ${ }^{* *}$
}

\section{Introduction}

With the publication of Groups and the Equal Protection Clause, ${ }^{1}$ Owen Fiss inaugurated the antisubordination tradition in legal scholarship of the Second Reconstruction. Antisubordination theorists contend that guarantees of equal citizenship cannot be realized under conditions of pervasive social stratification and argue that law should reform institutions and practices that enforce the secondary social status of historically oppressed groups. As elaborated by Fiss and subsequent proponents, including Catharine MacKinnon, Charles Lawrence, Derrick Bell, Laurence Tribe, and Kenneth Karst, this principle is variously called the antisubordination principle, the antisubjugation principle, the equal citizenship principle, or the anticaste principle. ${ }^{2}$ The latter expression evokes the famous statement of John Marshall Harlan in Plessy v. Ferguson that there is no caste in the United States, ${ }^{3}$ as well statements made by framers of the Fourteenth Amendment that the amendment was designed to prohibit "class legislation" and practices that reduce groups to the position of a lower or disfavored caste. ${ }^{4}$ Fiss

\footnotetext{
* Knight Professor of Constitutional Law and the First Amendment, Yale Law School.

** Nicholas deB. Katzenbach Professor of Law, Yale Law School.

${ }^{1}$ Owen M. Fiss, Groups and the Equal Protection Clause, 5 PHIL. \& PUB. AfF. 107 (1976).

2 See, e.g., Derrick Bell, AND We Are Not SAVEd: The Elusive QuEST FOR RACIAL Justice (1987); Kenneth L. KARSt, Belonging to AmERICA: EquAl Citizenship AND the

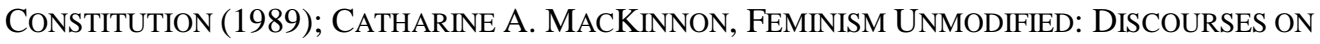
LiFE AND LAW 32-45 (1987); CATHARINE A. MaCKInNON, SEXUAl Harassment OF Working WOMEN 117 (1979) (arguing that courts should inquire "whether the policy or practice integrally contributes to the maintenance of an underclass or a deprived position because of gender status"); LAURENCE TRIBE, AMERICAN CONSTITUTIONAL LAW, §16-21, at 1043-52 (1978); Charles R. Lawrence III, The Id, the Ego, and Equal Protection: Reckoning with Unconscious Racism, 39 STAN. L. REV. 317, 319 (1987). Each of us writes in the antisubordination tradition as well. See, e.g., J.M. Balkin, The Constitution of Status, 106 YALE L.J. 2313 (1997 ); Reva B. Siegel, Why Equal Protection No Longer Protects, 49 STAN. L. REV. 1111 (1997).

${ }^{3}$ Plessy v. Ferguson, 163 U.S. 537, 559 (1896).

4 See Cong. GlobE, 39th Cong., 1st Sess. 674 (1866)(remarks of Senator Sumner)(proposed Fourteenth Amendment would abolish "oligarchy, aristocracy, caste, or monopoly with particular privileges and powers."); CONG. GLOBE, 39th Cong., 1st Sess. 2766 (1866)(remarks of Senator Howard)(goal of Fourteenth Amendment was to "abolis[h] all class legislation .... and [do] away with the injustice of subjecting one caste of persons to a code not applicable to another.") See also
} 
called his version of the antisubordination approach the "group disadvantaging principle" and he defined it as the principle that laws may not "aggravate" or "perpetuate" "the subordinate status of a specially disadvantaged group.",

A fairly standard story about the development of antidiscrimination jurisprudence since the 1970s argues that the views of Fiss and other antisubordination theorists were rejected by the U.S. Supreme Court, which adopted a contrary and inconsistent theory of equality. This approach is sometimes called the anticlassification or antidifferentiation principle. Roughly speaking, this principle holds that the government may not classify people either overtly or surreptitiously on the basis of a forbidden category, for example, their race. We add the word "surreptitiously" because a law that does not explicitly classify by race may nevertheless be motivated by an invidious purpose to differentiate on the basis of race, and most people think that this also counts as a violation of the anticlassification or antidifferentiation principle.

When Fiss talks about the anticlassification approach in his 1976 article, he calls it the "antidiscrimination" principle. ${ }^{6}$ In hindsight, this choice of words was quite unfortunate, because there is no particular reason to think that antidiscrimination law or the principle of antidiscrimination is primarily concerned with classification or differentiation as opposed to subordination and the denial of equal citizenship. Both antisubordination and anticlassification might be understood as possible ways of fleshing out the meaning of the antidiscrimination principle, and thus as candidates for the "true" principle underlying antidiscrimination law.

In this essay we challenge the common assumption that, during the Second Reconstruction, the anticlassification principle triumphed over the antisubordination principle. We argue instead that the two principles are better understood as regulating overlapping groups of practices and that their application shifts over time, in response to social contestation and social struggle. Analyzed from this historical vantage point, American civil rights jurisprudence vindicates both anticlassification and antisubordination commitments, even as the antisubordination principle sits in perpetual judgment of American civil rights law, condemning its formalism, compromises, and worldly limitations, and summoning it to more socially transformative ends.

Adamson v. California, 332 U.S. 46, 51 n.8 (1947) (quoting Sumner's resolution as evidence of meaning of Fourteenth Amendment); ANDREw KuLL, THE COLOR-BLIND CONSTITUTION 74-75 (1992).

${ }^{5}$ Fiss, supra note 1 , at 157.

${ }^{6} \mathrm{Id}$. at passim. 
The idea of distinguishing between anticlassification and antisubordination principles arose at a critical juncture in American race history. Fiss authored his pathbreaking article proposing the "group disadvantaging principle" in 1976, two decades after Brown, ${ }^{7}$ when American law had discredited the most prominent and overtly discriminatory practices enforcing racial segregation. At this juncture in the struggle over disestablishing Jim Crow, the Court faced important questions about the constitutionality of two kinds of practices: practices that employed racial criteria to integrate formerly segregated institutions and practices that preserved the racial segregation of institutions through formally neutral rules that made no overt reference to race. The stakes were high. Depending on how the Court dealt with the legality of affirmative action and the legitimacy of facially neutral practices with a disparate impact on racial minorities, the Constitution would either rationalize or destabilize the practices that sustained the racial stratification of American society now that the most overt forms of segregation were abolished.

The questions facing the Court put in issue the very meaning of Brown and the civil rights movement. If the Court read Brown as invalidating segregation on the ground that it violated an anticlassification principle, then facially neutral practices with disparate impact on racial minorities would be presumptively constitutional, while affirmative action would not. On the other hand, if the Court read Brown as invalidating segregation on the ground that it violated an antisubordination principle, then affirmative action would be presumptively constitutional, while facially neutral practices with a disparate impact on minorities would not.

In point of fact, segregation under Jim Crow violated both the anticlassification and antisubordination principles. ${ }^{8}$ Cases like Brown and Loving ${ }^{9}$ contained language condemning the practice of classifying citizens by race as well as language condemning practices that enforced subordination or inflicted status harm. For example, Brown argued that "[t]o separate [Negro children] from others of similar age and qualifications solely because of their race generates a feeling of inferiority as to their status in the community that may affect their hearts and minds in a way unlikely ever to be undone." ${ }^{10}$ Loving argued that " $\mathrm{t}]$ he fact that Virginia prohibits only interracial marriages involving white persons demonstrates that the racial classifications must stand on their own

\footnotetext{
${ }^{7}$ Brown v. Bd. of Educ., 347 U.S. 483 (1954).

${ }^{8}$ The separate but equal doctrine in public schooling helps subordinate blacks to whites. But it also involves an overt racial classification: pupils are assigned to different schools on the basis of race. Similarly, an antimiscegenation statute can be viewed as classifying on the basis of race (whites cannot marry blacks, blacks cannot marry whites) or as enforcing a system of racial hierarchy by prohibiting intermarriage of its superordinate and subordinate classes.

${ }^{9}$ Loving v. Virginia, 388 U.S. 1 (1967).

${ }^{10}$ Brown, 347 U.S. at 493.
} 
justification, as measures designed to maintain White Supremacy." ${ }^{11}$ Depending on whether one emphasized the anticlassification or antisubordination discourse in Brown and Loving, the cases seemed to resolve the disputes facing the Court quite differently.

Fiss advanced the group-disadvantaging principle as a framework in which to read Brown, so that Brown could be doctrinally elaborated in ways that would continue the work of disestablishing racial segregation. By developing the antisubordination values of cases like Brown and Loving into an independently justified "group-disadvantaging principle" and differentiating that principle from an anticlassification principle, Fiss sought to guide the Court in resolving the central questions of racial equality it faced in the mid 1970s. Fiss and the audience of Groups and the Equal Protection Clause understood the anticlassification and antisubordination principles to have divergent practical implications for the key issues of the moment: ${ }^{12}$ The anticlassification principle impugned affirmative action, while legitimating facially neutral practices with a racially disparate impact, ${ }^{13}$ while the antisubordination principle impugned facially neutral practices with a racially disparate impact, while legitimating affirmative action. ${ }^{14}$ Given the way Fiss and his audience understood the practical entailments of the two principles, it seems plausible to say that, during the 1970s and 1980s, the Court decided to vindicate anticlassification rather than antisubordination commitments. After all, today Davis, ${ }^{15}$ Feeney, ${ }^{16}$ Croson $^{17}$ and Adarand ${ }^{18}$ are the law of the land. If one defines the anticlassification and antisubordination principles solely with reference to these doctrinal debates, one might well conclude that the Court has never embraced the antisubordination principle in its Fourteenth Amendment case law.

But anticlassification and antisubordination are more than short-hand

\footnotetext{
${ }^{11}$ Loving, 388 U.S. at 11.

${ }^{12}$ Fiss observed that in "first-order" situations, such as the kind of segregation that prevailed in the 1940s, the two principles overlapped; that in "second-order situations" such as the case of facially neutral practices with a disparate impact, the antidiscrimination principle could be stretched to reach the result that the group-disadvantaging principle would reach; but that in "third-order situations" such as affirmative action, "there is a genuine conflict of principles." Fiss, supra note 1 , at 171 .

${ }^{13}$ Part III of Fiss's article, entitled "The Limitations of the Antidiscrimination Principle" is devoted exclusively to demonstrating these two points. See id. at 129-46.

${ }^{14}$ In Part IV of his article, Fiss demonstrates the application of the group-disadvantaging principle with respect to the "preferential treatment" and "de facto discrimination" questions. See id. at 159-164 (preferential treatment), 165-68 (state practices that aggravate the subordinate position of specially disadvantaged groups).

${ }^{15}$ Washington v. Davis, 426 U.S. 229 (1976).

${ }^{16}$ Personnel Adm'r v. Feeney, 442 U.S. 256 (1979).

${ }^{17}$ City of Richmond v. J.A. Croson Co., 488 U.S. 469 (1989).

${ }^{18}$ Adarand Constructors v. Pena, 515 U.S. 200 (1995).
} 
references for the holdings of this group of cases; legal scholars regard them as principles that can be abstracted from disputes in a particular historical context and applied to guide resolution of disputes in other cases. If we understand anticlassification and antisubordination as principles in this ordinary sense, the claim that the Court has never embraced the antisubordination principle in its Fourteenth Amendment decisions fundamentally mischaracterizes this body of law. In the end, we will show, it is just as plausible to describe American civil rights law as vindicating antisubordination as antidiscrimination commitments.

Our argument proceeds both analytically and historically. As we demonstrate in the opening sections of this essay, the anticlassification principle cannot by itself decide many important issues of antidiscrimination law. A decisionmaker must adopt additional criteria in order to apply the principle so that it can decide concrete cases. These implementing criteria cannot be derived from the anticlassification principle itself, and, as a result, many different legal regimes could be consistent with the anticlassification imperative.

Yet the indeterminacy of the anticlassification principle is not what interests us here; instead we focus on the interpretive discretion courts exercise as they apply the principle. Courts must make a variety of implementing decisions in order to apply the anticlassification principle; and, as we show, they do not make such implementing decisions in any consistent manner. Inconsistency in the ways that courts have implemented the anticlassification principle, over time and in different parts of the law, suggests that the discourse of anticlassification conceals other values that do much of the work in determining which practices antidiscrimination law enjoins.

Using this method of analysis, we can see that many values guide application of the anticlassification principle, among them, an interest in preserving or dismantling status relations. More particularly, we demonstrate how application of the principle shifts over time in response to social contestation. As social protest delegitimates certain practices, courts are often moved, consciously or unconsciously, by perceptions of status harm to find violations of the anticlassification principle where they saw none before. Considered from this historical vantage point, American civil rights jurisprudence vindicates both anticlassification and antisubordination commitments.

If antisubordination values are already playing a crucial role in guiding application of the anticlassification principle, why was it so important for Fiss and other scholars specifically to identify and advocate an antisubordation approach? In the concluding section of our essay, we explain the historical significance of Fiss's contribution.

Fiss and other progressive scholars developed the antisubordination approach at a crucial moment in the history of the Second Reconstruction. They sought to make express values that had guided civil rights law in order to criticize 
the political and juridical retreat from the civil rights movement that was occurring in during the 1970s. In elaborating the group-disadvantaging principle, Fiss emphasized that the American civil rights tradition had always been concerned with the subordination of social groups and the need to dismantle unjust social structures. By distilling these understandings and values into the form of an independently justified principle, Fiss attempted to intervene in the civil rights debates of the 1970s in more decisive terms than the discourse of anticlassification would allow. Fiss framed the nation's civil rights heritage in terms that posed a stark choice, advancing the group-disadvantaging principle to counter the arguments of those who were attempting to use anticlassification discourse to domesticate civil rights law and bring an end to the Second Reconstruction.

Of course, as we know, the American legal system did not embrace the group-disadvantaging principle with all the doctrinal implications Fiss and his audience understood it to entail. But it has never repudiated the antisubordination values that animated Brown and Loving and that continue to guide development of antidiscrimination law today. Taken together, the analytical and historical arguments of this essay challenge the conventional assumption that Groups and the Equal Protection Clause charts a road not taken. The antisubordination tradition, we argue, far from being a stranger to American civil rights law, remains its heart, its hope, and its pride.

\section{Indeterminacies in the Anticlassification Principle}

Most people would agree that the practical reach of an antisubordination principle is open to debate. The question of what practices or utterances or institutional arrangements might be subordinating involves interpretive judgments about social meaning, status, and the like, each of which is plainly contestable. And, there are a host of contestable value judgments entailed in determining what dignitary distinctions or distributive arrangements are unjust, and how the legal system should integrate the pursuit of antisubordination commitments with other social goals. Finally, the question whether a practice violates an antisubordination principle depends heavily on factual and historical contexts, and, in particular, on the laws and social mores that prevail in a given society at a given moment in history. In short, it is relatively uncontroversial to assert that the practical reach of the antisubordination principle is open to debate at any given historical moment, and shifts in incidence over time.

Few would characterize the anticlassification principle as similarly flexible. The anticlassification principle seems to define discrimination solely with reference to the structure of a social practice: It is wrong to distribute goods and opportunities on the basis of certain kinds of group membership. Unlike the 
antisubordination principle, the anticlassification principle would seem to state an objective and determinate rule of distribution that can be applied without additional value judgments. ${ }^{19}$ In what follows we demonstrate that the seeming objectivity of the anticlassification principle is illusory; a variety of social concerns shape its application, included but not limited to, interests in preserving, and in disestablishing, status relations.

The principle that social goods should not be distributed on the basis of group membership is not self-implementing. There are a variety of subsidiary questions that the legal system must answer if the anticlassification principle is to function, not as a abstract slogan, but as a principle capable of determinate and consistent application. As we examine the way the American legal system has resolved these implementation decisions, we discover that the anticlassification principle has not in fact been applied consistently, at any given moment in history, or over time. And as we observe inconsistency in the decision rules that courts have used to implement the anticlassification principle, we can appreciate how judges have applied the principle so as to accommodate competing social values and preserve status-linked institutions, practices, and understandings. This same method of analysis reveals how judges have shifted application of the anticlassification principle in response to social protest that discredits statusenforcing practices. As Brown and Loving illustrate, concerns about status harm that drive application of the antisubordination principle may move judges to find violations of the anticlassification principle where they saw none before.

Brown and Loving openly address the role that concerns about status harm play in judgments that the anticlassification principle has been violated. But such concerns need never be openly expressed or even fully conscious to play a role in guiding application of the antidiscrimination principle. Once protest illuminates the dignitary and distributive injuries that certain practices inflict, newly-tutored intuitions about the justice of the practice may move judges to make the kind of implementation decisions that result in a judgment that the anticlassification principle has been violated. Judges can make such implementation decisions without noticing them as such, and certainly without deliberating in categories of status harm and the like.

Demonstrating the role antisubordination norms have explicitly or implicitly played in influencing courts to find violations of the anticlassification principle is a vast undertaking. What we can show in this brief essay is the space of discretion within which such normative cross-fertilization occurs. The ensuing discussion demonstrates that: (1) the anticlassification principle cannot be applied without a variety of subsidiary decisions about how to give the principle practical effect; (2) the American legal system makes such implementation decisions

\footnotetext{
${ }^{19}$ But see Fiss, supra note 1, at 121 ("And there is ... nothing mechanical about the antidiscrimination principle. The promise of value neutrality is only an illusion.”)
} 
inconsistently; and (3) inconsistency in the decision rules used to implement the antidiscrimination principle allows the principle to be applied in ways that accommodate competing social values, preserve status-linked practices and understandings, and, at times, shift in response to social protest discrediting a practice that inflicts status-harm.

We begin by listing some of the kinds of implementation decisions that judges must make if they are to apply the anticlassification principle as a rule that can actually determine the outcome of legal controversies. Our examples also demonstrate inconsistencies in the implementation decisions American courts have made in applying the anticlassification principle:

\section{What is the structure of a policy or practice that classifies "on the basis" of group membership?}

(A) Does a policy violate the anticlassification principle if group membership is only one of multiple selection criteria, or must group membership be the sole criterion of selection? There turns out to be no clear answer to this question. When affirmative action programs employ race as one of multiple selection criteria (a "plus" as Justice Powell once called $\mathrm{it}^{20}$ ), the use of race triggers strict scrutiny. Yet, courts have ruled that the use of race in adoption placements or suspect descriptions is permissible and will not trigger strict scrutiny, so long as race is not the "sole" criterion of selection. ${ }^{21}$

(B) What if a policy employs criteria that predominantly, but not exclusively, select group members? Most often we assume that "group-salient" selection criteria, whose incidence falls primarily, but not exclusively, on members of one group, do not classify on the basis of group membership: it is for this reason that we say that rules that discriminate on the basis of veteran-status are not sex-based ${ }^{22}$ and that rules that discriminate between crack and powder

\footnotetext{
${ }^{20}$ See Regents of the University of California v. Bakke, 438 U.S. 265, 317-18 (1978) ("race or ethnic background may be deemed a 'plus' in a particular applicant's file, yet it does not insulate the individual from comparison with all other candidates for the available seats. The file of a particular black applicant may be examined for his potential contribution to diversity without the factor of race being decisive when compared, for example, with that of an applicant identified as an Italian-American if the latter is thought to exhibit qualities more likely to promote beneficial educational pluralism.”)

${ }^{21}$ See R. Richard Banks, The Color of Desire: Fulfilling Adoptive Parents' Racial Preferences Through Discriminatory State Action, 107 YALE L.J. 875, 904-06 (1998) [hereinafter Banks, Color of Desire]; R. Richard Banks, Race-Based Suspect Selection and Colorblind Equal Protection Doctrine and Discourse, 48 U.C.L.A. L. REV. 1075, 1095-96 (2001) [hereinafter Banks, Race-Based Suspect Selection].

${ }^{22}$ See Personnel Adm'r v. Feeney, 442 U.S. 256 (1979).
} 
cocaine-possession are not race-based. ${ }^{23}$ Instead we generally insist that selection criteria must be "group-categorical," affecting only group members and no others. Yet, at times we treat group-salient criteria as classifying on the basis of group membership, as when we say that grandfather clauses (which limited the franchise to those whose ancestors had the right to vote) discriminated against black voters, or that the bar on same-sex marriage (which operates regardless of the parties' sexual orientation) discriminates against gays. When the legal system prohibits individuals from engaging in covert and purposeful discrimination, it is generally constraining the conduct of individuals who use group-salient, rather than group-categorical, criteria to distribute access to goods or opportunities.

(C) How formalized and public must breaches of the anticlassification principle be? If implicit or hidden acts of classification are constrained by the principle, what scienter standard should be used to measure covert breaches of the principle? What evidentiary presumptions will we use to determine whether the anticlassification principle has been breached? As we develop in greater detail below, American antidiscrimination law answers these questions differently in different contexts.

(D) What distributive or dignitary harm must a challenged classification inflict? Application of the anticlassification principle turned on such questions in Plessy when the Court ruled that separate but equal public facilities did not discriminate because they inflicted no harm on the separated groups. ${ }^{24}$ The Court categorically rejected this approach in Brown, ${ }^{25}$ and seems to reject such an approach today when it applies strict scrutiny to affirmative action on the ground that it cannot reliably distinguish benign and invidious discrimination. ${ }^{26}$ On the other hand, courts seem to act on the belief that a group-based classification must inflict some dignitary or distributive harm to violate the anticlassification principle when they uphold the use of race in census or suspect descriptions on the ground that the classification is permissible because it merely describes social realities. ${ }^{27}$

\footnotetext{
${ }^{23}$ See United States v. Clary, 34 F.3d 709 (8th Cir. 1994), cert denied, 513 U.S. 1182 (1995).

${ }^{24}$ Plessy, 163 U.S. at 551 ("We consider the underlying fallacy of the plaintiff's argument to consist in the assumption that the enforced separation of the two races stamps the colored race with a badge of inferiority. If this be so, it is not by reason of anything found in the act, but solely because the colored race chooses to put that construction upon it.")

${ }^{25}$ Brown, 347 U.S. at 495 ("We conclude that in the field of public education the doctrine of "separate but equal" has no place. Separate educational facilities are inherently unequal.")

${ }^{26}$ See City of Richmond v. J.A. Croson, 488 U.S. 469, 493 (1989).

${ }^{27}$ Compare Brown v. City of Oneonta, 221 F.3d 329, 337-38 (1999) (upholding use of race in suspect descriptions), and Morales v. Daley, 116 F. Supp. 2d 80, 814 (S.D. Tex. 2000) (holding
} 
2. Are superordinate and subordinate groups equally protected? Are groups occupying superordinate and subordinate positions in status hierarchies equally protected from the harm of classification based on group membership? In United States v. Carolene Products Corp. ${ }^{28}$ the Court suggested that judicial scrutiny applied to laws burdening discrete and insular minorities, thus implying that courts should review laws burdening non-discrete or non-insular majorities differently. In Adarand, the Court seemingly rejected this view. The majority began its case for applying strict scrutiny to affirmative action by embracing a principle of "consistency of treatment irrespective of the race of the burdened or benefited group." 29 Yet, at the same time, the majority also insisted that a court applying strict scrutiny would have sufficient knowledge of racial status in the United States to distinguish between "'remedial preferences [and] invidious discrimination' ... or, more colorfully, 'between a 'No Trespassing' sign and a welcome mat." ${ }^{30}$ The principle of consistency, it turns out, renders all affirmative action suspect, but it still allows the state to give remedial benefits to members of racially subordinate groups that it may not give to members of racially superordinate groups.

\section{To what spheres of social life does the anticlassification principle apply?}

The anticlassification principle has never been applied to all situations and all spheres of social life. For example, there are activity-centered limitations on the anticlassification principle, such as the $19^{\text {th }}$ century distinction between political, civil, and social rights, and agent-centered limitations on the anticlassification principle, such as the distinction between public and private actors. Today the state action requirement is an important, if inconsistently defined, agent-centered limitation on the anticlassification principle. While state action doctrine may limit the reach of the anticlassification principle, it is commonly assumed that all use of race by state actors is subject to strict scrutiny. This is not in fact the case, for the reach of the anticlassification principle is sometimes blocked by another agent-

that census questions concerning race and ethnicity do not violate the Fourteenth Amendment: "Statistical information as such is a rather neutral entity which only becomes meaningful when it is interpreted. ... Plaintiff's position is based upon a misunderstanding of the distinction between collecting demographic data so that the government may have the information it believes at a given time it needs in order to govern, and governmental use of suspect classifications without a compelling interest."), with Anderson v. Martin, 375 US. 399, 402 (1964) (holding that a Louisiana statute, which mandated the designation of a candidate's race on election ballots, violated equal protection because it enlisted the power of the state to enforce private racial prejudices.)

${ }^{28} 304$ U.S. 144,152 n. 4 (1938).

${ }^{29}$ Adarand, 515 U.S. at 226-27.

${ }^{30} I d$. at 229. 
centered limitation that allows state actors to use race (for example, in adoption placement decisions, suspect descriptions, and innumerable census-linked determinations), so long as private citizens rather than state officials supply the racial criteria employed. ${ }^{31}$ By inconsistently applying these agent-centered limitations on the anticlassification principle (along with variable standards for proving other agent-centered limitations, such as the discriminatory purpose requirement), the law covertly preserves something like the old activity-centered limitations on the anticlassification principle in modern form, enforcing civil equality while preserving various elements of social inequality. ${ }^{32}$

The way the legal system answers the implementation questions we have posed give the anticlassification principle the only bite it has. Take two practical examples: The police issue a directive for officers to round up young black men driving expensive sports cars. An employer fires a saleswoman who is about to have a baby. One cannot say whether either of these activities violates the anticlassification principle without further specification of how the principle should be applied. For long periods of time practices like these were thought not to violate the anticlassification principle; but now, under some facts, and under some elaborations of the principle, one can argue that each hypothetical violates the principle. Such examples are by no means exceptional. Unless the anticlassification principle is supplemented by a set of further specifications, boundary conditions, and implementing rules that are consistently applied, the practical consequences of the principle are quite uncertain. As we shall now demonstrate, the antidiscrimination principle by itself does not make clear what values should guide selection of these implementing rules, nor does it provide sufficient normative guidance to determine the scope of their application.

\section{Dilemmas of Implementing the Anticlassification Principle}

\footnotetext{
${ }^{31}$ See, e.g., Oneonta, 221 F.3d at 337-38 (plaintiffs "were not questioned solely on the basis of their race. They were questioned on the altogether legitimate basis of a physical description given by the victim of a crime. . . . In acting on the description provided by the victim of the assault--a description that included race as one of several elements--defendants did not engage in a suspect racial classification that would draw strict scrutiny. The description, which originated not with the state but with the victim, was a legitimate classification within which potential suspects might be found.") See also Banks, Color of Desire, supra note 25, at 880-82; Banks, Race-Based Suspect Selection, supra note 21, at 1093-94.

${ }^{32}$ See infra text accompanying notes 42-48 (discussing inconsistent application of scienter standards for proving discriminatory purpose); Siegel, supra note 2, at 1139 (observing that inconsistent application of discriminatory purpose doctrine "perpetuates, in a new juridicial framework, distinctions between 'political' and 'social' rights of the sort that once undergirded the Court's decision in Plessy").
} 
The anticlassification principle cannot by itself resolve fundamental questions concerning its practical implementation. The law concerning so-called "invidious motivation" is a good example. It has long been understood that a doctrine that subjects racial classifications to judicial scrutiny must be supplemented by a rule that includes some laws that do not classify by race on their face. The classic examples are the so-called grandfather clauses, which restricted the right to vote unless a person's ancestor had been able to vote before Reconstruction. ${ }^{33}$ Grandfather clauses were not necessarily race categorical--for it was possible that free blacks in the antebellum period might technically have had voting rights and that some descendants of whites were not themselves legally white-- but it was generally understood that they were racial classifications because their presumed intentions and effects were to disenfranchise blacks.

Obviously, courts could deny that the grandfather clauses violated equal protection or the Fifteenth Amendment. But they have not done so out of a fear that this degree of formalism would effectively subvert larger principles of equality. In Guinn \& Beal v. United States, for example, Justice White argued that upholding the grandfather clause in the Oklahoma Constitution would reduce the Fifteenth Amendment to a nullity. Similarly, it was not sufficient for the Court in Brown to declare unconstitutional laws that assigned school attendance on the basis of overt racial criteria. In Green v. New Kent County School Board ${ }^{34}$ the court held that a facially neutral policy of "school choice" would predictably preserve white and black identified schools and that the continued existence of such schools violated the Fourteenth Amendment. In Keyes ${ }^{35}$ and subsequent cases the Court felt it necessary to adopt burdens of proof, presumptions and other doctrines that would facilitate equal protection challenges to school systems whose attendance policies contained no express racial criteria, but whose schools were populated by racially distinct student bodies. ${ }^{36}$

In short, implementation of the anticlassification principle cannot turn on matters of legal form alone. As these examples suggest, the bar on overt racial classifications requires an additional injunction against hidden or implicit racial classifications if it is to have any practical significance. Thus, courts inevitably move to supplement the anticlassification principle with a doctrine that prohibits disparate treatment under facially neutral criteria. As they do so, the anticlassification principle threatens to lose all determinate application, unless courts adopt standards by which implicit acts of disparate treatment can be

\footnotetext{
${ }^{33}$ See, e.g., Guinn \& Beal v. United States, 238 U.S. 347 (1915).

${ }^{34} 391$ U.S. 430 (1968).

${ }^{35}$ Keyes v. School Dist. No. 1, Denver, Colorado, 413 U.S. 189 (1973)

${ }^{36}$ See, e.g., id. at 208 ("[W]e hold that a finding of intentionally segregative school board actions in a meaningful portion of a school system, as in this case, creates a presumption that other segregated schooling within the system is not adventitious.")
} 
proved. But it is not at all clear what criteria, if any, the anticlassification principle supplies to guide the choice of such standards.

Suppose that the state adopts reading comprehension tests for prospective police officers, with full knowledge that using the tests will exclude four times as many blacks as whites. Is this a forbidden implicit racial classification? Is mere knowledge of the racial consequences sufficient or does there have to be a showing of specific intent to exclude blacks from employment as police officers? If so, how should the requirement of specific intent be implemented with respect to corporate or bureacratic decisionmakers? What criteria are relevant to determining whether invidious motivation is present? Should it matter whether the selection criterion that excludes four times as many blacks as whites is unrelated to the tasks the employees are to perform? Does the number and race of the applicants excluded bear on this question?

American law has not answered these questions consistently. For constitutional purposes, Washington v. Davis ${ }^{37}$ holds that mere negligence or actual knowledge of disparate impact is not sufficient to prove a violation of the Equal Protection clause. A plaintiff must prove that state actors adopted the challenged policy with the specific purpose of discriminating against a protected class. Plaintiffs may, however, ask factfinders to infer discriminatory purpose from evidence of disparate impact. Contrast this with judicial interpretation of Title VII, a statute that regulates both public and private employers. Griggs $v$. Duke Power Co. ${ }^{38}$ holds that practices having a disparate impact on blacks and women violate Title VII if such practices are not justified by a business necessity. This rule also might be said to implement the anticlassification principle if one views facially neutral practices with disparate racial impact that are not justified by business necessity as implicit forms of disparate treatment. There is good support for this view. Title VII allows plaintiffs to rebut employer claims of business necessity by showing that the claims of business necessity are in fact pretextual. $^{39}$ Equally important, the Court in Griggs justified the disparate impact rule as necessary to counteract previous acts of disparate treatment by the

\footnotetext{
${ }^{37}$ Washington v. Davis, 426 U.S. 229 (1976).

${ }^{38}$ Griggs v. Duke Power Co., 401 U.S. 424 (1971).

${ }^{39}$ See Albermarle Paper Co. v. Moody, 422 U.S. 405, 425 (1975). The Court has emphasized ties between the disparate impact and disparate treatment inquiries. See Watson v. Fort Worth Bank \& Trust, 487 U.S. 977, 990-91 (1988) ("We are also persuaded that disparate impact analysis is in principle no less applicable to subjective employment criteria than to objective or standardized tests. In either case, a facially neutral practice, adopted without discriminatory intent, may have effects that are indistinguishable from intentionally discriminatory practices. . . Furthermore, even if one assumed that any such discrimination can be adequately policed through disparate treatment analysis, the problem of subconscious stereotypes and prejudices would remain. . . . If an employer's undisciplined system of subjective decisionmaking has precisely the same effects as a system pervaded by impermissible intentional discrimination, it is difficult to see why Title VII's proscription against discriminatory actions should not apply.")
} 
employer and by others in society, including segregated school districts. ${ }^{40}$ The Griggs court viewed employment practices with a disparate impact that could not be justified by business necessity as implicitly classifying on the basis of race. Whether the anticlassification principle should be so implemented-rather than by a rule that treats all practices with a disparate impact as potential evidence of discriminatory purpose ${ }^{41}$--cannot be decided by reference to the anticlassification principle itself. Instead, it should by now be clear that one might articulate different versions of the anticlassification principle through such doctrinal frameworks. One can explain both Washington v. Davis and Griggs v. Duke Power as implementing the anticlassification principle-or as inconsistent with it-depending on how one reasons about the problem of implicit classifications.

The same problem of deciding among possible implementation regimes reappears even if one insists that the problem of tacit classification should be policed through a requirement of discriminatory purpose. Exactly how should the legal system define discriminatory purpose? In Feeney ${ }^{42}$ the Court held that to demonstrate discriminatory purpose, plaintiffs must show that state actors adopted the challenged action at least in part because of and not merely in spite of its impact on a protected class. ${ }^{43}$ Feeney's gloss on Davis was surely not compelled by the anticlassification principle, and indeed, it is not used in ordinary employment cases charging sex discrimination. A plaintiff does not have to show that an employer refused to hire her in order to hurt her or to harm women generally. Rather, it is enough that the decision was based on gender stereotypes that may be entirely paternalistic.

In fact, the rule of Feeney is a particularly narrow way of conceiving the scope of the anticlassification principle, for proving a mental state approximating malice is nearly impossible in a legal culture that celebrates equal opportunity and insists that in public, at least, people keep their most inegalitarian sentiments to themselves. Yet, as it turns out, the Supreme Court and lower federal courts have not consistently enforced Feeney's definition of discriminatory purpose. Instead federal courts have implemented the discriminatory purpose doctrine of Washington $v$. Davis quite differently in different factual contexts. ${ }^{44}$ The scienter standard and the evidentiary presumptions necessary to prove discriminatory

\footnotetext{
${ }^{40}$ See Griggs, 401 U.S. at 430 ("Under the Act, practices, procedures, or tests neutral on their face, and even neutral in terms of intent, cannot be maintained if they operate to 'freeze' the status quo of prior discriminatory employment practices."); see also id. ("Because they are Negroes, petitioners have long received inferior education in segregated schools....").

${ }^{41} C f$. Keyes v. School Dist. No. 1, Denver, Colorado, 413 U.S. 189, 234-36 (1973) (Powell, J., concurring) (arguing against maintaining the de jure/de facto distinction in school desegregation cases).

${ }^{42}$ Feeney, 442 U.S. 256 (1979).

${ }^{43} I d$. at 279.

${ }^{44}$ Daniel Ortiz, The Myth of Intent in Equal Protection, 41 STAN. L. REV. 1105, 1107 (1989).
} 
purpose vary considerably in accordance with intuitions about the importance of the good whose distribution is contested or about the likelihood of bias in the transaction. Accordingly, Feeney rules are not applied in voting cases, jury cases, or school degregregation cases. ${ }^{45}$ On the other hand, Feeney's narrow definition of discriminatory purpose has been employed to block equal protection challenges to veterans' preferences ${ }^{46}$ and to laws that impose heightened penalties on crimes involving crack cocaine ${ }^{47}$ or lesser sanctions on crimes involving domestic violence. $^{48}$

The problem with finding criteria to guide application of the anticlassification principle is not limited to doctrines concerning implicit classifications. It haunts doctrines concerning explicit classifications as well. Exactly what is a classification that discriminates "on the basis of" race or sex? As Section II illustrates, there are a variety of inconsistencies in the way the American legal system makes this determination. To consider just one example, must group membership be the sole criterion of distribution or can it be one of multiple factors? The anticlassification principle supplies no guidance in selecting among these different implementation regimes. ${ }^{49}$ In fact, American antidiscrimination law shuttles back and forth between different implementation rules in different contexts. In the next section, we begin to explore some of the underlying values that drive these inconsistent patterns of implementation.

\section{Values that Guide Application of the Anticlassification Principle}

Consider how Title VII regulates the use of express, sex-based criteria in employment policies. Courts have ruled that an employer who refuses to hire women with preschool age children while hiring men with preschool age children

\footnotetext{
${ }^{45} \mathrm{Id}$. at $1119-34$.

${ }^{46}$ Feeney, 442 U.S. 256 (1979).

${ }^{47}$ See Siegel, supra note 2, at 1139-40.

${ }^{48}$ See Id. at $1140-41$.
}

${ }^{49}$ Consider another example involving explicit classifications. Antidiscrimination law generally holds that practices discriminate on the basis of group membership when the practice distributes goods in accordance with group-categorical rather than group-salient criteria. The challenged practice must advantage or disadvantage a class exclusively populated by persons of one status identity or another. For example, under current legal doctrines the state does not discriminate on the basis of sex when it refuses to give domestic labor the same recognition as other forms of work or fails to criminalize marital rape-nominally because the exemptions are group-salient, rather than group-categorical: they disadvantage most women and some men. Yet courts have not consistently limited the anticlassification prinicple to group-categorical classifications. In proscribing implicit group-based classifications, antidiscrimination law regularly polices groupsalient distributions. To apply Brown in a meaningful way, courts had to invalidate school assignment practices in districts where there was some degree of racial mixing in school attendance patterns. See supra note 36 and accompanying text. 
discriminates on the basis of sex. ${ }^{50}$ At the same time, courts consistently hold that an employer who refuses to hire men who wear dresses while hiring women who wear dresses, or who refuses to hire women who wear pants while hiring men who wear pants, does not explicitly discriminate on the basis of sex. ${ }^{51}$ The doctrine that treats only some "sex-plus" policies as discriminating on the basis of sex thus allows employers to publish and enforce sex-specific grooming codes. ${ }^{52}$ The court that first developed the sex-plus strategy frankly acknowledged that it did not want to interpret the statute in ways that would too greatly disrupt conventional forms of business practice. ${ }^{53}$ Presumably, courts do not view sexspecific grooming codes as enforcing the kind of sex discriminatory treatment Title VII is supposed to prohibit. This intuition might translate roughly either as the notion that the statute shouldn't interfere with normal and perfectly reasonable ways of doing business, ${ }^{54}$ or that excluding men who wear dresses from the workplace doesn't keep women down. ${ }^{55}$

We see the same dynamic at work in the ways that antidiscrimination law regulates policies that use race as an explicit criterion of selection. When courts consider the constitutionality of affirmative action in education or government contracting, government use of race as one factor in the decision counts as

\footnotetext{
${ }^{50}$ Phillips v. Martin Marietta Co., 400 U.S. 542 (1970).

${ }^{51}$ Lanigan v. Bartlett \& Co. Grain, 466 F. Supp. 1388, 1391 (W.D. Mo. 1979).

${ }^{52}$ Courts treat "sex-plus" policies as explicitly discriminating on the basis of sex in violation of Title VII only when the "plus" is a fundamental right or immutable trait. See Willingham v. Macon Tel. Pub. Co., 507 F.2d 1084, 1091-92 (5th Cir. 1975).

${ }^{53} I d$. at 1090-91 ([T] he meager legislative history regarding the addition of "sex" in Sec. 703(a) provides slim guidance for divining Congressional intent. The amendment adding "sex" . . . was introduced by Representative Howard Smith of Virginia, who had opposed the Civil Rights Act, and was accused by some of wishing to sabotage its passage by his proposal of the "sex" amendment.... Congress in all probability did not intend for its proscription of sexual discrimination to have significant and sweeping implications.... A line must be drawn between distinctions grounded on such fundamental rights as the right to have children or to marry and those interfering with the manner in which an employer exercises his judgment as to the way to operate a business.")

${ }^{54}$ Sometimes courts are quite forthright, as was the Sixth Circuit in a famous opinion denying a hostile work environment sex harassment claim. See Rabidue v. Osceola Refining Co., 805 F.2d 611 (6th Cir. 1986) ("Indeed, it cannot seriously be disputed that in some work environments, humor and language are rough hewn and vulgar. Sexual jokes, sexual conversations and girlie magazines may abound. Title VII was not meant to -- or can -- change this. It must never be forgotten that Title VII is the federal court mainstay in the struggle for equal employment opportunity for the female workers of America. But it is quite different to claim that Title VII was designed to bring about a magical transformation in the social mores of American workers.") (citation omitted).

${ }^{55}$ But see Mary Anne C. Case, Disaggregating Gender from Sex and Sexual Orientation: The Effeminate Man in the Law and Feminist Jurisprudence, 105 Y.L.J 1 (1995). And what of the failure to protect women who wear pants? See Lanigan v. Bartlett \& Co. Grain, 466 F. Supp. 1388, 1391 (W.D. Mo. 1979).
} 
discrimination on the basis of race that is subject to strict scrutiny. Yet a different implementing rule is used in other contexts. Courts have ruled that adoption placement policies or suspect descriptions that employ race as part of a multiplecriteria selection policy do not trigger strict scrutiny, so long as race is not the "sole" criterion of selection. Again, inconsistency in the decision rules used to implement the anticlassification principle arises as courts endeavor to apply the anticlassification principle in a manner that constrains practices that seem to judges to inflict racial injustice, while enabling practices that seem to judges innocent of discriminatory animus and that serve other important social ends.

In other words, when doctrine inconsistently defines what counts as a classification that will trigger application of the anticlassification principle, it is generally because other values are implicitly or explicitly guiding application of the anticlassification principle. Inconsistent resolution of such implementation questions may reflect judicial efforts to accommodate other widely shared values, or it may arise because the courts are trying to preserve traditional, status-based understandings and practices from the reach of antidiscrimination law. In addition, these inconsistencies may emerge as courts come to discern violations of the anticlassification principle in response to social movement litigation and protest that discredits status-enforcing understandings and practices.

We can see such doctrinal inconsistencies arise and dissipate in the years following Brown's determination that separate can never be equal. The Court quickly applied that principle to municipal facilities like cafeterias, water fountains, and golf courses. Nevertheless, when asked to apply the principle that decided Brown to antimiscegenation laws a year later in Naim, ${ }^{56}$ the Court avoided the question for more than a decade, until it finally decided that antimiscegenation laws violated the Equal Protection Clause in $1967,{ }^{57}$ the same year that Guess Who Is Coming to Dinner? won an Academy Award. The deferral of the Loving decision illustrates how application of the anticlassification principle is guided by public intuitions concerning the legitimacy of practices employing group distinctions.

Sexual harassment law provides another example. Courts once ruled that sexual harassment did not amount to discrimination on the basis of sex, because, among other reasons, even if the harasser directed his attention to members of one sex only, he did not harass all members of the group. ${ }^{58}$ After social movement

\footnotetext{
${ }^{56}$ See Naim v. Naim, 350 U.S. 891 (1955)(remand for further proceedings); Naim v. Naim, 350 U.S. 985 (1956)(dismissal of appeal for want of jurisdiction).

${ }^{57}$ Loving v. Virginia, 388 U.S. 1 (1967).

${ }^{58}$ See Barnes v. Costle, 561 F.2d 983, 990 (D.C. Cir. 1977) (ground of discrimination not sex, but refusal "to furnish sexual consideration"); Williams v. Saxbe, 413 F. Supp. 654, 657 (D.D.C.

1976) ("since the primary variable in the claimed class is willingness vel non to furnish sexual consideration, rather than gender, the sex discrimination proscriptions of the Act are not invoked").
} 
protest and litigation, courts came to view harassing conduct of this sort as sexbased discrimination. ${ }^{59}$ Yet, this shift in the application of the anticlassification principle did not move courts similarly to adjust other applications of the principle. Years after it emphatically recognized that sexual harassment was sex discrimination, ${ }^{60}$ the Court continued to rule that discrimination against pregnant women is not discrimination on the basis of sex because it affects some but not all women $^{61}$ - although the Court's attempt to apply this analysis of pregnancy discrimination to Title VII met with social movement protest and was soon thereafter reversed by statutory amendment. ${ }^{62}$

The basic point should by now be clear: the doctrines implementing the anticlassification principle shifted in the case of sexual harassment, not because of any moral or philosophical principle inherent in the concept of classification, but because of sustained political contestation about an existing social practice. With this in mind, consider again how courts have applied the anticlassification principle to the use of race in suspect descriptions. Courts currently reason that the state may employ race in suspect descriptions so long as race is not the sole factor used to detain suspects. ${ }^{63}$ The same rationale once shielded affirmative action programs from invalidation-- the Harvard plan that used race as only one factor was the canonical example of permissible affirmative action offered in Justice Powell's opinion in Bakke. ${ }^{64}$ Yet this " race plus" narrative ultimately gave way in the face of sustained social movement protest by conservatives and the installation of judges hospitable to their views. ${ }^{65}$ Courts now look upon all

\footnotetext{
${ }^{59}$ For an extended analysis of sexual harassment doctrine as a case study in the workings of antidiscrimination law, see Reva Siegel, 'On the Basis of Sex': A Short History of Sexual Harassment, in DiRECTIONS IN SEXUAL HARASSMENT LAW (Catharine A. MacKinnon \& Reva B. Siegel, eds., forthcoming 2004).

In making the case that sexual harassment was sex-based discrimination, Catharine MacKinnon argued both from the anticlassification and antisubordination standpoint. See MACKINNON, supra note 2, at 117 (arguing that courts should inquire "whether the policy or practice integrally contributes to the maintenance of an underclass or a deprived position because of gender status"). Indeed her argument in Sexual Harassment of Working Women is an early and influential exploration of the antisubordination principle that remains one of its most powerful and comprehensive expressions.

${ }^{60}$ Meritor Savings Bank v. Vinson, 477 U.S. 57 (1986).

${ }^{61}$ See Geduldig v. Aiello, 417 U.S. 484, 496 n. 20 (1974) ("The lack of identity between the excluded disability and gender as such under this insurance program becomes clear upon the most cursory analysis. The program divides potential recipients into two groups--pregnant women and nonpregnant persons. While the first group is exclusively female, the second includes members of both sexes."), reaffirmed in Bray v. Alexandria Women's Health Clinic, 505 U.S. 1240 (1992).

${ }_{62}^{62}$ Pregnancy Discrimination Act of 1978, 42 U.S.C. $§ 2000 \mathrm{e}(\mathrm{k})(2000)$.

${ }^{63}$ Oneonta, 221 F.3d 329, 337-38 (1999).

${ }^{64}$ See Bakke, 438 U.S. 265, 317-18 (1978) (Powell, J.) (discussing the constitutionally valid use of race as a "plus" factor in admissions policies).

${ }^{65}$ See Croson, 488 U.S. 469 (1989).
} 
affirmative action programs with suspicion, even if race is only one factor. Perhaps, after a decade or so of sustained challenge to the use of race in profiling and suspect descriptions, courts will one day come to apply heightened scrutiny to the use of race in detaining criminal suspects ${ }^{66}$-- although the events of September 11 have no doubt diminished the likelihood and imminence of such reform.

In short, application of the anticlassification principle often depends on judgments concerning the presence, absence, or degree of status-harm-- the very sorts of judgments with which the antisubordination principle is concerned. These judgments may be conscious or unconscious, explicit or implicit, and they shift in time, in response to social mobilizations and other developments. But they are present, nevertheless, in the evolving ways that Americans understand the practical implications of the anticlassification norm. The claim, then, that during the closing decades of the Second Reconstruction, the Court embraced the anticlassification principle and repudiated the antisubordination principle profoundly misdescribes the movements of American civil rights law.

\section{Conclusion: Making the Implicit Explicit}

If, as we have argued, antisubordination values have often guided application of the anticlassification principle in practice, how should we understand the significance of Fiss's articulation of the group disadvantaging principle in 1976? We close with some reflections on the historical significance of Groups and the Equal Protection Clause.

Following World War II, the struggle for civil rights transformed American law and society. We can understand this transformation as the product of both anticlassification and antisubordination values. As we have seen, in Brown and in Loving the Supreme Court repudiated $19^{\text {th }}$ century conceptions of discrimination and equality by invoking both anticlassification and antisubordination ideas. In time, this new body of constitutional and statutory antidiscrimination law began to break down entrenched forms of segregation and subordination that had characterized American society since the Civil War.

By the mid 1970's the legal system, prodded along by the Civil Rights movement, had produced genuine changes in American social life and in the behavior and belief of millions of Americans. Jim Crow laws, de jure racial segregation, and related practices of overt racial subordination were now widely discredited. Indeed, these changes, which redefined black and white identity in a very short period of time, were so revolutionary that they provoked an urgent reaction from the white majority. A year after the Supreme Court's decision in

\footnotetext{
${ }^{66}$ See Banks, Race-based Suspect Selection, supra note 21, at 1096-1108 (demonstrating similarity of race-based profiles and suspect descriptions).
} 
Loving, the 1968 election signaled the beginning of a gradual retrenchment that would bring an end to the Second Reconstruction. Political reaction to the Second Reconstruction was mirrored in a jurisprudential reaction. Beginning in the 1970's the federal courts applied existing doctrines in ways that slowed the project of disestablishing racial hierarchy, thus achieving a compromise on race relations that large numbers of whites sought. ${ }^{67}$

Lack of judicial vision does not explain the increasing formalization and rigidity of the Burger Court work. Rather, the judicial response reflects a loss of political will to continue the work of the Second Reconstruction. The paths that the Court took in cases like Milliken v. Bradley, ${ }^{68}$ San Antonio Independent School District v. Rodriguez, ${ }^{69}$ and Washington v. Davis, ${ }^{70}$ were by no means foreordained by previous doctrinal choices. Rather, the distinctions created in these cases worked to cut short continuing racial reform, as progressives like Fiss who lived through this period well understood.

It was in these circumstances that antisubordination theory was born. Faced with a shifting political landscape and an increasingly unresponsive judiciary, Fiss believed that it was important to describe how this emerging body of constitutional jurisprudence diverged from important understandings and commitments that he believed were at the heart of the struggle for civil rights. A "transvaluation of values" was proceeding apace in political and judicial rhetoric, blunting the energy and the impulse of the Second Reconstruction; the Court had begun to define, in ever more narrow ways, the practices and utterances that would henceforth count as classification, intention, and injury in the eyes of the law

All of this transpired in a legal landscape transformed by the civil rights movement itself. As civil rights law discredited the most overt and notorious forms of racial discrimination, sites of controversy shifted, and the project of abolishing racial segregation assumed new doctrinal forms. On the one hand, the

\footnotetext{
${ }^{67}$ To given only one example, it has become clear by the end of this century that public schools may be segregated by race as long as it is not done so officially or by direct fiat. See Jack M. Balkin, Brown v. Board of Education: A Critical Introduction, in WHAT BROWN V. BOARD OF EDUCATION SHOULD HAVE SAID: THE NATION's TOP LEGAL EXPERTS REWRITE AMERICA's MOST FAMOUS CIVIL RIGHTS OPINION 8 (Jack M. Balkin ed., 2001); See generally Gary Oren et al., Resegregation in American Schools, available from http://www.law.harvard.edu/civilrights/alerts/reseg.html (last visited August 27, 2002) (describing the trends toward resegregation of public elementary and secondary schools in the past twenty-five years).

${ }^{68}$ Milliken v. Bradley, 418 US 717 (1974)(Milliken I) (imposing strict limits on interdistrict desegregation plans).

${ }^{69} 411$ U.S. 1 (1973)(holding that education is not a fundamental right and that inequalities of educational opportunity caused by unequal funding do not violate the Constitution).

${ }^{70} 426$ U.S. 229 (1976)(holding that only proof of specific intent to discriminate on the basis of race justifies strict scrutiny of government policies under the Equal Protection Clause).
} 
Court was faced with questions concerning the use of race conscious remedies to integrate formally segregated institutions; on the other hand, it was increasingly called upon to address facially neutral practices that perpetuated racial segregation in most institutions of American life. Debate about these politically fraught questions took the form of a dispute about the principles and commitments that Brown and the civil rights movement embodied. Did Brown repudiate racial classifications only-or something more?

Groups and the Equal Protection Clause squarely engaged this debate. Fiss well understood that formulating antidiscrimination norms solely in terms of forbidden classifications would (1) legitimate facially neutral practices that perpetuated racial segregation and (2) discredit race-conscious remedies that might ameliorate racial segregation. In other words, he appreciated that reasoning about racial equality in terms of forbidden classifications would limit the reach of racial reform, by prohibiting practices that were already receding in frequency and significance, while leaving untouched practices that would henceforth do most of the work in preserving racial stratification in American society.

At the same time, Fiss appreciated there were important questions of movement history at stake in this debate. Describing the quest for racial equality in terms that focused exclusively on forbidden acts of classification omitted crucial chapters in the history of civil rights struggle, and obscured defining aspects of the movement's self-understanding, values, and spirit. Yet racial conservatives now claimed that African-Americans had always couched their demands in anticlassification discourse, and that radical elements in the civil rights movement were hypocritically abandoning the principles that had brought African-Americans justice and redemption. In this way, racial conservatives who had no professed no great love for the social changes of the 1950's and 1960's could now insist that they, and not their opponents, were the true inheritors of the mantle of Brown v. Board of Education and the civil rights movement-that they, and not their more progressive critics were the real disciples of Thurgood Marshall and Martin Luther King.

What was occurring in the 1970s, in short, was not simply a struggle over politics, or even a struggle over law. It was also a struggle over cultural memory, over the narrative that defined what Americans as a nation had accomplished. It was a struggle over how Americans would understand and remember the principles that animated the civil rights movement.

Fiss's intervention at this particular historical moment was important precisely in order to contest this transvaluation of values. The point of disaggregating the principle of equality into antisubordination and anticlassification strands, and naming the idea of antisubordination as a principle worth fighting for, was to preserve an understanding of the American civil rights 
tradition and the impulses within it that had allowed it to succeed. Equality, Fiss reminded us, is not just the Aristotelian insistence that like cases be treated like. It is about the struggle against subordination in societies with entrenched social hierarchies. It is about the lived experience of people on the bottom who strive for dignity and self-respect. And it is about the structures and strategies, institutions and practices that continually deny them this prize all the while professing to bestow it.

Fiss's project was to show that antisubordination as well as anticlassification ideas had played a crucial role in the development of American civil rights law. It was necessary to separate them and name them at that historical juncture because a failure of political will sought to dignify one conception of equality and forget and suppress the other, and in this way preserve racial hierarchies and status relations in a more benign guise. ${ }^{71}$ By reinterpreting and remembering the civil rights movement through the formalist lens of anticlassification, white America could more easily believe that racial inequality was a thing of the past; and that it had done-and nobly done-everything it needed to do to make whites and blacks equal citizens before the law. Fiss and the other antisubordination theorists who followed him challenged this complacent self-understanding. Together, they sought to create a conscience for the American legal system.

All of this puts Fiss's work-and the antisubordination tradition-in its proper context. It may well be the case that many in the country wanted a cooling off period after the rapid changes in social structure and social practices that followed Brown and the civil rights movement. But it does not follow that the antisubordination tradition was foreign to that revolution. Far from it: The development of antisubordination as a distinct approach to the problem of equality stemmed directly from the reluctance of politicians, the Supreme Court, and the country to continue a project in which they had already been engaged. ${ }^{72}$ The antisubordination tradition should hardly be discredited because it was not

\footnotetext{
${ }^{71}$ For fuller elaborations of this argument, see J.M. Balkin, Ideological Drift and the Struggle over Meaning, 25 CONN. L. REV. 869 (1993) (evaluating this history with attention to questions of "ideological drift"); Siegel, supra note 2, (analyzing the reform of racial status law during the first and second reconstructions as examples of "preservation through transformation").

${ }^{72}$ Cf. Reva B. Siegel, Discrimination in the Eyes of the Law: How "Color Blindness" Discourse Disrupts and Rationalizes Social Stratification, 88 CALIF. L. REV. 77, 111-12 (2000), reprinted in PREJUDICIAL APPEARANCES (Duke Press 2001) ("Fiss's 'group- disadvantaging principle' thus began the work of translating the status-disestablishing commitments of the Second Reconstruction into rhetorical terms better adapted to challenging the status-enforcing practices of the civil rights era. . . On this account, then, Fiss and those who followed him sought a new language in which to describe the assault on racial stratification already initiated during the Second Reconstruction in the language of color blindness itself.")
} 
embraced at a particular point in American history by people who sought to blunt, obstruct, and end our nation ₹ Second Reconstruction.

Yet that is precisely what has happened. Most Americans-including most contributors to this symposium - assume that American civil rights law has never recognized the principle of antisubordination or group disadvantage. We refuse such a conclusion. We do so because it is false to reason and principle. But equally important, we do so because it is false to memory. To claim that the struggle for equality in this country has not been about subordinated groups seeking to dismantle the social structures that have kept them down makes a travesty of American history. The moral insistence that the low be raised upthat the forces of subordination be named, accused, disestablished, and dissolved - is our story, our civil rights tradition. It is what has made that tradition anything that anyone ever had reason to be proud of. The antisubordination principle is not some alien, discredited Other, some reckless theoretical sally wisely avoided and marginalized by cooler heads. It is the expression of the American revolutionary tradition in our own time, the living source of our commitment to the Declaration and its promises of equality, the warm lifeblood of the American spirit. It points, sometimes proudly, sometimes defiantly, but always honestly, to what we have done, to what we should have done, and to what we have yet to do. 